\title{
Anti-Idiotype Antibody
}

National Cancer Institute

\section{Source}

National Cancer Institute. Anti-ldiotype Antibody. NCI Thesaurus. Code C16296.

An antibody directed ag ainst the individual antigenic determinants (idiotopes) on the variable region of an immunog lobulin molecule. In principle an anti-idiotype antibody should inhibit a specific immune response and they are important to the regulation of the immune system. 